\title{
Canadian Schools in Transition: Moving From Dual Education Systems to Inclusive Schools ${ }^{12}$
}

\author{
Judy Lupart \& Charles Webber \\ The University of Calgary
}

\begin{abstract}
This paper provides a synthesis of educational reforms in Canadian schools over the past century to present times. The unique emphasis is to document the broad movements of change in both special and regular education. We begin our analysis with a detailed discussion on the many meanings of school restructuring and highlight the ongoing nature of school reform. Following a selective chronology of general and special education reform, we attempt to capture what appear to be the key features of school reform and progressive inclusion. The numerous obstacles to school reform are outlined and the evolving roles of those most centrally connected with the school culture-teachers, students, and parents-are reviewed. Several conditions for successful change are presented and the adoption of a balance of interests, policies, principles, and practices is recommended along with a transformation from dual systems to a unified system of education for all students. Regular and special educators are the professionals who must make school transformation reflect excellence and equity in our Canadian schools, and all available resources and support need to be deployed to this end.
\end{abstract}

Following the trend established in the latter part of the 20th century, education continues to be held under close scrutiny. Alarms have been sounded on several fronts, including industry, governments, educational institutions, parents, and students (Elmore, 1990; Goens \& Clover, 1991; Hepburn, 1999; Levin, 2001a; Mann, 1978; Vaughan, 2002; Whitty, Power, \& Halpin, 1998). There is wide-scale concern that our education systems have become mediocre, and consequently our human resources are being underdeveloped and underutilized. High dropout rates, lower achievement scores in comparison to other industrialized countries, failure to deliver widespread literacy, and charges that students are not adequately prepared for the work force are perhaps the most frequently cited concerns (Kaminsky, 2000; National Association of Secondary School

\footnotetext{
${ }^{1}$ Paper first published in 2002, Exceptionality Education Canada, 12(2), 7-52.

2 This paper is an updated version of a chapter in Lupart, J., McKeough, A., \& Yewchuk, C. (Eds.). (1996). Schools in transition: Rethinking regular and special education. Scarborough, ON: Nelson.
} 
Principals, 1992; National Commission on Excellence in Education, 1983). In addition, growing numbers of students, such as those who have physical, behavioural, or cognitive disabilities, and many others coming from dysfunctional families and economically disadvantaged or culturally different backgrounds, are at-risk of failing in current educational systems (Cuban, 1989; Lupart, Goddard, Hebert, Jacobsen, \& Timmons, 2002; Schonert-Reichl, 2000). Policies and procedures that have traditionally served the needs of students and adequately fulfilled the expectations of the public have increasingly come under attack (Darling-Hammond, 1993; Fuhrman, 1993; Glickman, 1991; Robertson \& Webber, 2000; Sarason, 1990) and more recently, there have been strong pressures placed on schools to implement practices borrowed from business to privatize some of their services and to provide job training for students (Tanner, 2000).

Beginning in the 1980s, a major movement toward school reform and school restructuring was generated in the general education system (Goodlad, 1984; National Commission on Excellence in Education, 1983). As a result, several initiatives including movements for effective schools, school improvement, cooperative learning, site-based management, and teaching excellence have been implemented and evaluated in both the academic and popular literature (Bliss, Firestone, \& Richards, 1991; Davis \& Thomas, 1989; Harris \& Chapman, 2002; Johnson, Johnson, \& Holubec, 1986; Lieberman, 1992). Special education, with its unique history and organizational configuration, has also shown a gradual but steady progression toward the present inclusive education emphasis (Andrews \& Lupart, 2000; Meyen \& Skrtic, 1995; Reynolds, 1989; Stainback \& Stainback, 1992). Concepts such as integration, normalization, mainstreaming, least restrictive environment, and the Regular Education Initiative (REI) are associated with the notion of serving the unique learning needs of exceptional students in community schools within a unified educational system.

In many respects, the current directions of school change in general and special education systems appear headed for collision. Efforts to accommodate changes emanating from one system or the other have been piecemeal and fragmented and clearly have not worked (Elmore, 1990; Gartner \& Lipsky, 1996; Liberman, 1992; Lipsky \& Gartner, 1989; Sashkin \& Egermeier, 1992; Skrtic, 1996; Stainback \& Stainback, 1996; Wang, 1996; Wang, Reynolds, \& Walberg, 1994). During a time of worldwide trend toward reduced government funding for education (Taylor, 2001), these two systems have become increasingly competitive for the diminishing resources that are available. Many educational reform leaders are calling for a radical overhaul of traditional educational systems, including changes to the philosophical, pedagogical, organizational, and theoretical dimensions. At the very core of restructuring movement is the recognition that, currently conceived, separate systems of regular and special education need to be dramatically transformed and conjoined so our schools can more effectively meet the needs of all students. Although many educators agree that this kind of change is essential to significant educational improvement, there is considerable confusion regarding the most effective means for achieving this goal. What happens in the next few years as a result of educational change movements will no doubt determine "what" an appropriate education will be and "whether" it will be appropriate for all students (Haberman, 2000), particularly educationally challenged and gifted students (Andrews \& Lupart, 2000; Audette \& Algozzine, 1992; Lupart et al., 2002).

One of the most salient limitations of current educational restructuring literature is the undue separation of regular and special education focus and concern. Reform leaders in general education have concentrated their efforts on raising standards, teacher preparation and accountability, school organization and policy, and rarely address or even mention the issues concerning students with challenging learning needs, whereas special education reformers make this their focus almost entirely. Clearly, contemporary school change efforts need to begin the simultane- 
ous examination of issues concerning regular and particularly special education before we can achieve excellence and equity in our schools. This is the central theme of this paper, since general reform literature has typically failed to incorporate sufficient coverage of issues pertaining to educationally challenged and gifted students.

\section{Understanding Restructuring}

The term "restructuring" was used often enough in the years leading to the start of the 21 st century and in a sufficient variety of contexts that it takes more than a little fortitude to ask someone to define it. This phenomenon becomes clear when one consults the school restructuring literature. For example, a relatively short, albeit broad, description is provided by Elmore (1990) who claimed that discussions of school restructuring usually are centred on three issues: the teaching of academic content with a focus on understanding and problem solving, the transfer of decision-making power to individual school communities, and teacher accountability. Goens and Clover (1991) offered a very similar description, except they included terms like decentralization, governance, and power. They also distinguished between "restructuring" and "transformation" by suggesting that the former addresses only structural issues while transformation occurs when education's purposes and their underlying values are altered fundamentally. The National Association of Secondary School Principals (1992) posed a more detailed description of restructuring. That definition, too, referred to issues of authority devolution, accountability, and power, but it also embraced instructional improvement, teacher professionalism, shared leadership, coordination of community resources, and student equality.

As useful as these descriptions are, they conceal a host of confusing and sometimes contradictory messages (Lieberman, 1992). For instance, the concept of decentralization appeals to many parents, teachers, and students, but insufficient attention has been given to the concern that increasing the power of particular stakeholders actually may decrease the control wielded by others. The language of restructuring fails to convey similar meanings to different people. Consequently, the terminology is employed by a wide range of individuals who often hold very different assumptions about teaching and learning. In fact, Elmore (1990) noted that the very ambiguity of the term restructuring may contribute to the wide popularity of the concept and that, when specific changes are implemented on broad scales, solidarity among school reformers may begin to dissipate. The problem is particularly salient when reform within special education is taken into consideration.

For special education, recent reform efforts have been concentrated on the REI. Though there are many interpretations of the essence of this movement, its roots can be traced to the widespread criticism of traditional, segregated special education service delivery and policy, and deinstitutionalization (Lloyd, Singh, \& Repp, 1990). Special education criticism parallels the impetus for reform in the general education system in the 1980s. The more distinguishing aspect of special education reform stems from a general trend toward the normalization of persons with disabilities and/or handicaps that was predominant in the 1960s and 1970s. Based upon issues of human rights and natural social justice, advocates such as Wolfensberger and his associates (Wolfensberger, 1984; Wolfensberger, Nirge, Olshansky, Perske, \& Roos, 1972) lobbied for the removal of persons with disabilities from institutions into home communities where they could have better access to educational and living environments as close to normal as possible. Within the schools this trend was actualized in the practice of integration and mainstreaming. Together these two trends resulted in calls for a closer alliance of general and special education (Wang, 1996; Wang \& Reynolds, 1985; Will, 1986) and for some critics a complete restructuring and merging of the two systems into a unified system of education (Gartner \& Lipsky, 1996; Lipsky 
\& Gartner, 1989; Stainback \& Stainback, 1996; Stainback, Stainback, \& Bunch, 1989b). Thus the REI was largely defined as a movement to promote greater synchrony of general and special education and was promoted on the assumption that this kind of union would help to eliminate some of the major shortcomings of both systems. Beyond the call for an improved unified education, Fuchs and Fuchs (1994) specifically noted two associated thrusts of reversing the alarming increase of special education services for high-incidence students with learning disabilities, behaviour disorders, and mild or moderate mental disability, and, through the provision of improved instruction in the mainstream education system, the prevention of school failure for large numbers of at-risk students without any apparent disabilities.

Though the movement was seen initially as offering great promise, the failure of special education to form a productive alliance with general education (Fuchs \& Fuchs, 1994) and the ill-fated special educational compromise of endorsing the least restrictive environment as a means of engendering greater inclusion (Bunch, 1994; Lupart, 1998; Skrtic, 1996) have resulted in minimal change and maximal controversy. Though legislative actions and educational policy changes to support inclusive education have been widely implemented in the United States and Canada, the general education system remains primarily concerned with issues associated with achieving excellence, and special education continues to struggle with the seemingly paradoxical problem of promoting educational equity for all students.

\section{Ongoing Nature of School Reform}

The wave of school reform throughout North America that occurred since the early 1980s was just one phase of a century-long effort to modify schools to meet the evolving needs of society (Georgiades \& Keefe, 1992; Presseisen, 1985). In the late 1800s and early 1900s, industrial and technological changes combined with labour, economic, and legal conditions to increase the number of young people who attended school during their adolescence (Powell, Farrar, \& Cohen, 1985). As a result, schools were altered in many ways (Goodlad, 1984). Students were grouped according to their ages and spent more time with peer groups than they did with their family members. An educational bureaucracy was formed and staffed by teachers and administrators whose professional training lengthened and became more structured, and the curriculum was expanded. In spite of the effort to include larger numbers of children in the education enterprise, students with exceptional needs were generally excluded from the general education system during this time period. Any available educational or training provisions were typically administered in large institutions where children with sensory or mental handicaps and behavioural problems were indiscriminately housed with other children who were poor, orphaned, or vagrant (Kauffman, 1981; Winzer, 1996). Though some early educational intervention for children with visual and hearing impairments was undertaken by the clergy and medical pioneers, educators were primarily engaged in building a viable public education system for the general student population.

It would be erroneous to conclude that educational change occurred without intense discussion, even conflict. Iterative patterns of industrialization, immigration, and urbanization throughout the 20th century supplied a ready source of controversy for school personnel and, indeed, society as a whole (Goodlad, 1984; Powell et al., 1985). In fact, North American education over the past 100 years has been characterized by heated and politicized debates over issues such as so-called new education, progressive education, excellence in education, school choice (Boyd, 2000; Georgiades \& Keefe, 1992; Parker \& Parker, 1995), and the integration of children with challenging needs into the schools (Andrews \& Lupart, 2000; Reynolds, 1989). 
It is interesting to note that, despite the ongoing nature of school reform, each era's proponents for change-including some of the most respected voices in education (see Lieberman, 1992; Sizer, 1984) - have stated quite categorically that reformers have caused little to change in schools. Lieberman (1992) claimed that teaching is still teacher-centred and based on the assumptions that teachers should control the learning environment and that learning is a passive activity for students. However, Cuban (1990) contested this sort of view by describing changes "of almost revolutionary proportions" (p. 27). He pointed to the access to schooling available to students from virtually all socioeconomic backgrounds, the growth of secondary schools to address a large variety of student needs, the amalgamation of schools and school districts, expanded programs and facilities, the professionalization of the teaching force, and modifications in governance structures as examples of large-scale and complex changes to both the substance and structure of education.

A central theme surrounding change in special education has been the movement toward "progressive inclusion" (Andrews \& Lupart, 2000; Reynolds, 1989). This refers to a gradual shift from the segregation and isolation of children with exceptional learning needs, particularly those having more severe or obvious forms of disability or handicap, to mainstreamed educational settings and programming within the child's home community. The ultimate goal for inclusive education proponents is to achieve equal access to free and appropriate schooling for all children in every community. Progress, at times halting yet steadily forward over the decades, has been stymied recently by the recognition that special education driven initiatives such as integration, mainstreaming, and the REI are doomed to failure without the full support and commitment of the regular education system.

There are other similarities among reform eras in the 20th century. One is the perception that the intensity of educational debate increased (Boyd, 2000; Levin, 1993; Murphy, 1991). Another consistent pattern is the belief that schooling in the past was better than in the present (Cuban, 1990; Webber, 1994). Within the ranks of special education, the controversy between those who seek the preservation of hard-fought gains in traditional special education programs and those who want to see a full-scale restructuring of general and special education into a more unified public education system has created deep divisions that threaten the philosophical and pedagogical foundations of the field (Fuchs \& Fuchs, 1994; Goodlad \& Lovitt, 1993; Lupart, 1998; Stainback \& Stainback, 1992). Beyond the heated debate within the special education and gifted education discipline is the broader question of the place of special education within the general education reforms. This can lead politicians and even educators to yearn for a perhaps mythical time when schools were more orderly, students better learners, and communities more supportive.

The foregoing suggests that school reform on this continent is a continuous process that is impossible to complete as long as societies and people continue to evolve. Of course there are regional, national, and international, not to mention temporal, differences in how and when educational change occurs (Levin, 1993, 2001a). Nevertheless, members of American and Canadian societies, in fact citizens of every nation, will persist in their efforts to change education in response to a plethora of internal and external influences.

\section{A Selective Chronology of Reform}

During the final two decades of the 19th century, North Americans began to increase their faith in schooling as a vehicle for the improvement of individuals and society. Even though proportionately fewer students had access to or the desire for studies beyond the elementary level, education began to be perceived as a vehicle for upward social mobility. In addition, industriali- 
zation and new child welfare laws had reduced employment for young people and increased the appeal of school as a social centre. These two factors combined to create a reasonably high level of societal support for school. In response, educators and community members expanded school programs and extracurricular activities, especially at the secondary level (Murphy, 1991; Powell et al., 1985). Children who were poor, disabled, and/or emotionally disturbed were often abandoned by their families, and custodial care was the norm as these already disadvantaged children were considered to be unworthy of an education (Stainback, Stainback, \& Bunch, 1989a). Any provisions and services that were available were typically outside the mainstream educational system and most often concentrated in institutions, reformatories, or special residential schools. Key medical and religious reformers in Canada and the United States led the struggle to create more humane treatment and positive circumstances for disadvantaged and disabled students, emphasizing the need for education and training.

\section{From 1900 to 1950}

Educational modifications in the period just before and after 1900 certainly were not free of conflict. High schools were criticized for what was perceived as a proliferation of courses at the expense of academic rigour. Concerns were aired about the positive and negative effects of social class on student achievement. The growing recognition of less-able students who were forced to repeat grades or drop out fueled criticisms concerning curriculum which was deemed appropriate for only the brightest students and the high costs of grade repetition was advanced as indications of the inefficiencies of public education. Commentators on that era (e.g., Murphy, 1991; Powell et al., 1985) declared that the governance structure of turn-of-the century schools was aligned too closely with an industrial model. Others raised concerns about the widespread exclusion of students with obvious disabilities or handicaps, significantly those labelled as mentally handicapped, from general education systems (Kauffman, 1981; MacMillan \& Hendrick, 1993). Furthermore, while citizens of that era placed great faith in school as a social institution, they were unwilling to back that faith with financial resources and respect for intellectual work.

Nevertheless a rising interest in the health, welfare, and education of children resulted in widespread faith in schools and continued to exist throughout the first three decades of the 20th century. This trend was notably beneficial for many disabled, poor, and orphaned students who were placed under the jurisdiction of schools. Widely acclaimed success in the education and training of children with handicaps in Europe generated a spirit of positivism that influenced the work of early special education reformers in Canada and the United States, and these innovative approaches and new instructional techniques formed a tenuous foundation of special education in North America (Hallahan \& Kauffman, 1991). Special programs for gifted students were introduced and developed during this period. Long-held myths and superstitions associated with persons with handicaps were replaced with the belief that rehabilitation and training could improve their lives and promote their self-sufficiency with the ultimate benefit to society. Unfortunately, a counter movement led by genetic scientists in the early 1900s emphasized the hereditary permanence of "feeble-mindedness," and was sufficiently forceful to instill the view that mental retardation was the cause of society's problems including crime, delinquency, poverty, prostitution, and immorality (Lusthaus \& Lusthaus, 1992), and eugenics and sterilization for persons with mental disabilities was widely sanctioned in society (Winzer, 1996). These contradictory views concerning children with exceptionalities, along with increased concerns about less able students who were failing within the general education system, forced the creation of special education classes and vocational programs. These gradually became accepted as successful reform measures. 
The Great Depression not only failed to suppress this belief: the 1940s and 1950s were decades of unprecedented expansion of the education systems in the United States and Canada. Education was seen as the means by which a rapidly growing student population, along with soldiers (many with physical and emotional disabilities) returning from the second World War, could contribute to the economic and social fabric of society. Any problems associated with disability, unemployment, intergenerational conflict, and social apathy could be ameliorated. Psychology became established as a field of professional study and practice and the scientific study of children, including the study of mental and physical disabilities, had a major impact on educational practice (Kauffman, 1981). Intelligence and achievement testing were established as a scientific basis for decisions concerning appropriate curriculum and placement of individual students (MacMillan \& Hendrick, 1993). The criticism of education that did exist focused mainly on the perceived quality of teachers, administrators, and teacher educators, rather than on schools per se (Goodlad, 1984; Powell et al., 1985; Presseisen, 1985).

\section{From 1950 to 1970}

The apparent general public satisfaction with schools during most of the 1950s was challenged in 1957 when the Soviet Union launched an unmanned space vehicle, Sputnik, into orbit around the earth. That triggered a burst of initiatives in math and science curricula (Goens \& Clover, 1991) that continued well into the 1960s, when the mandate of education was expanded still further. The launch of Sputnik also cultivated a new appreciation for the educational nurturing of gifted students and gave impetus to the development and expansion of separate and specialized programs from the 1960s on. Besides competition with the Soviets, communities and governments expected school programs and personnel to address a host of other issues: poverty, crime, civil rights, and racial discrimination, for example (Goodlad, 1984; Powell et al., 1985; Presseisen, 1985). During this time, society became increasingly supportive of schools as the most viable public institution to address social problems, such as handicapping conditions (MacMillan \& Hendrick, 1993) and, in the case of gifted programs, as an investment in future security and/or prosperity of the nation (Gallagher, 1991; Yewchuk, 1996).

During the 1960s and 1970s, several other major components of the North American framework for educating and socializing children underwent significant changes. First, roles within the family group evolved, with two working parents becoming the norm for children. This trend was exacerbated by the economic decline of the North American economy during the latter half of the 1970s (Goens \& Clover, 1991). Second, there were sharp increases in the numbers of children in single-parent families. These two conditions combined to reduce the influence of parents in children's education. Also, the authority of religion in children's lives declined to where it no longer was an educative force for most young people (Goodlad, 1984). A fourth influence on education was the reduced proportion of citizens directly associated with schools; predictably, there was a corresponding decline in public interest in supporting and trusting education. This was a contributing factor to an increased focus on accountability, efficiency, and mandated curricula (Darling-Hammond, 1993; Mann, 1978). Another noteworthy change had to do with how children were enculturated into adult roles: youngsters' values and attitudes were increasingly shaped by the electronic media. Finally, parental attitudes toward schools and teachers changed during the 1970s; public criticism of education expanded to include the institution of school per se, rather than the earlier focus upon the quality of teaching. In fact, there was a serious reduction in the degree to which the home and school were working toward common goals for children (Goodlad, 1984). 
During this period special education underwent dramatic changes as well. Parent advocacy groups; the civil rights movement; and advances in theory, diagnosis, and instruction for students with exceptional learning needs spurred the development and remarkable expansion of special education throughout North America. Classes initially targeted for students with pronounced or severe handicaps, soon after, rapidly emerged to include students with less obvious disabilities (i.e., learning disability, mild mental retardation, mild emotional disturbance) and these latter groups later became the focus for "considerable controversy, debate, and even litigation" (MacMillan \& Hendrick, 1993, p. 24). The proliferation of publicly funded special education schools and classes formed a separate, though parallel, system of education in the schools with more and more students being identified and more categories of service provided (Andrews \& Lupart, 2000; Yewchuk, 1996). The "five-box" special education approach, a one-way process of referral, testing, labelling, placement, and programming became well established in the public schools (Andrews \& Lupart, 2000). The specialization of teachers, teacher preparation programs, assessment and instructional methods, specialized professional and parent advocacy associations, research and publications, and auxiliary services, were all part of a well established, separately funded, second system of educational bureaucracy that became increasingly competitive with the general education system for funding, resources, and personnel (Bunch, 1994). Meanwhile, educators in the regular education system, faced with increasing expectations to extend subject matter and cover a massively increased knowledge base, were increasingly ready to "hand over" to special education any student whose learning or behaviour was beyond "normal" expectations.

The publication of Dunn's (1968) critical analysis of separate special education classes sparked a period of intense critical reflection in the special education field. Common special education practices including the widespread use of intelligence tests, indiscriminant special class placement of large numbers of students floundering in the general education system, the deleterious effects of classification and labelling, the disproportionate numbers of poor and cultural minority students enrolled in special education classes, and the efficacy of specialized programs were heavily scrutinized. These concerns dovetailed with a more pervasive and significantly positive shift in public attitudes toward disabled and handicapped individuals brought about by the deinstitutionalization and normalization movement (Andrews \& Lupart, 2000). Parents and advocacy groups lobbied for the integration of children with moderate and severe handicaps into community schools and classes, and predisposed educators rallied for the integration of students with mild handicaps into regular classrooms.

\section{From 1970 to Present}

Not surprisingly, after several decades of acquiescence to "specialized" services for challenging learners, teachers in regular education classrooms were generally less than welcoming to the notion of teaching classes of increasingly diverse students. Prevailing attitudes toward greater inclusion of persons with disabilities in communities and schools clashed mightily with educational practice, and the subtle resistance of the schools to make the appropriate changes was curbed through educational policy reform at the local level and more substantially through legislation.

The passage of Public Law 94-142 in the United States had a profound effect on special education service delivery in schools throughout North America. The basic intent of the law was to ensure a minimum standard of equitable service delivery for students with exceptional learning needs and to satisfy conflicting demands for appropriate educational services within the least restrictive environment, preferably within regular classroom settings. In practice, the results were a twofold compromise: students with more extreme forms of educational challenge were provided 
full-time placements in classrooms and programs as far as possible within their regular community schools, and the majority of students with mild or moderate educational challenge were primarily served in regular classroom settings with some part-time placement or provision of necessary specialized services (Andrews \& Lupart, 2000; Bunch, 1994). As general education began to shift toward these more inclusionary practices, it became increasingly apparent that regular classroom teachers and administrators were insufficiently prepared and ill equipped to effect the multidimensional and complex changes that inclusive education reformers had envisioned. Within the ranks of special education, deep divisions began to surface concerning the conceptual foundations of student exceptionality and education, how quickly change should be implemented, the extent of change in traditional special education delivery, which students with challenging learning needs might potentially benefit from inclusion education, and the level of confidence in the ability of the general education system to satisfactorily implement inclusive education (Andrews \& Lupart, 2000; Bunch, 1994; Fuchs \& Fuchs, 1994; Gartner \& Lipsky, 1996; Kauffman \& Hallahan, 1993; MacMillan \& Hendrick, 1993; Meyen, 1995; Reynolds, Wang, \& Walberg, 1987; Stainback \& Stainback 1996). Significantly, the reform literatures emanating from general and special (including gifted) education followed radically different courses and prescriptions for change consistently failed to reflect the issues and perspectives of the other system.

A flurry of reports and commentaries on American education appeared throughout the 1980s. The reports contained a variety of descriptions of how general education should be reformed. The authors were motivated by a strong concern about the quality of schools and called for the almost total rebuilding of the educational system, occasionally looking to countries such as Japan for educational models (Carnegie Forum on Education and the Economy, 1986; Powell et al., 1985). Goodlad (1984) suggested that some of the public concern about education corresponded to an overall loss of faith in public institutions, even though parents tended to think their own children's schools were providing a good education. Others (e.g., Carnegie Forum on Education and the Economy, 1986; Powell et al., 1985) stated their belief that schools simply had assumed more responsibilities than they possibly could meet. Whatever their origin, concerns about the quality of education led to a series of suggestions advocating increased controls, accountability, efficiency, and practical outcomes (Carnegie Forum on Education and the Economy, 1986; Rowan, 1990).

The National Commission on Excellence in Education (1983) produced what was likely the most influential of the reports from the 1980s - A Nation at Risk. The document contained a series of accusations against schools, curricula, and teachers of mismanagement, incompetence, and mediocrity. The report's authors claimed that American students were spending too little time in school working with superficial materials and subject content taught by academically inferior teachers who were insufficiently prepared for their work. This state of affairs was said to have resulted in low student achievement, grade inflation, and widespread illiteracy. The report included the claim that the average citizen of that era was better educated and more informed than Americans one generation earlier, but that the average graduate from schools and colleges had an education inferior to that of the average graduate in the prior generation. Rather than claiming the overall improvement a victory for public education, the report presented the situation as a cause for alarm. It is important to note that the Nation at Risk document was in many ways a political statement, replete with inflammatory terminology and hyperbole employed to alarm Americans and solidify support for educational restructuring. In this regard, the report achieved its purpose. 
Included in the 1980s campaign for school reform was a series of recommendations for improving the teaching force. To combat the perception that teachers were drawn from the ranks of those with low academic ability, it was suggested that the undergraduate degree in education be abolished. In its place, pre-service teachers should be required to complete a bachelor's degree in the arts and sciences before undertaking the professional study of teaching, perhaps at the graduate level. Teacher education programs could be improved further by being conducted in professional development schools under the highest and most rigorous standards. Other recommendations included increasing teachers' salaries, implementing differentiated teaching careers, recruiting teachers from minority groups, and increasing public respect for teachers (Carnegie Forum on Education and the Economy, 1986; Cornett, 1995; Holmes Group, 1986; Kearns \& Doyle, 1988; Rowan, 1990).

Efforts to reform schools continued into the 1990s throughout North America and in English-speaking countries abroad. The dominant themes to emerge were school choice, schoolbusiness partnerships, competition among students and teachers, national standards and curricula, and concurrent moves to centralize and devolve decision-making power (see Boyd, 2000; Carnoy, 2000; Poetter \& Knight-Abowitz, 2001; Whitty et al., 1998). Well-known examples of school reform guided by these themes occurred in Britain, Australia, and New Zealand (Bates, 2002; Levin, 1993, 2001a). Lobbying efforts (Kearns \& Doyle, 1988) and even legislation (Webber, 1995) supporting similar reforms appeared in both Canada and the United States in recent years, despite cautions that such moves challenged the assumption of equal access to education for children from all socioeconomic backgrounds (Carnoy, 2000; Schlechty, 1990a). Interestingly, Canadian and U.S. reforms in the 1990s were manifested in specific goals designed to achieve pre-eminence in international tests, particularly in subjects like math and science (Keys, 1997). Americans, especially, sought to make academic excellence more achievable by reducing or eliminating violence, drugs, and student drop-outs from the daily life in schools (National Association of Secondary School Principals, 1992; National Education Goals Panel, 1991).

Reform efforts in special education throughout the 1980s and 1990s became increasingly fragmented as leading figures within the discipline have attempted to articulate and critically analyze the advantages and limitations associated with the REI and inclusive education (Fuchs \& Fuchs, 1994; Kauffman \& Hallahan, 1993; Lloyd, 2000; Lloyd et al., 1990; Skrtic, 1991, 1996). At one extreme we find a cadre of reformers who want rapid and total inclusive education. Arguing from a moral, ethical base these proponents have called for the elimination of special education with the full integration of all students into the regular education system (Gartner \& Lipsky, 1996; Lipsky \& Gartner, 1989; Stainback \& Stainback, 1996; Stainback, Stainback, \& Forest, 1989). At the other extreme, proponents have argued for a continuation of a continuum of pull-out special education options and services and have raised serious concerns about the ability of the general education system to provide appropriate education for educationally challenged and gifted children, and a greater fear of losing the hard-fought resources, specialized service, and expertise that have been amassed over several decades in special education (Fuchs \& Fuchs, 1994; Kauffman \& Hallahan, 1993). In the middle of this special education polarization has come the REI proponents who assert that

(a) too many students are labelled as handicapped, especially as learning disabled; (b) too much time is spent on determining eligibility, and too little attention is focused on how to meet students' learning needs; (c) 'pull-out' programs, the effectiveness of which have yet to be documented, fragment instruction; and (d) separate classes for 'handicapped' learners are morally indefensible. (Audette \& Algozzine, 1992, p. 10) 
This dissention becomes more pronounced as the various interest groups within the special education field examine their likely place in the broader context of general education reform as reflected in special issues in gifted education (Gifted Child Quarterly, 1991, 35[1]), and learning disabilities (Journal of Learning Disabilities, 1988, 21). Importantly, articles and special theme issues about inclusive education and special education within the context of general education reform were beginning to emerge in the general education literature as well-Educational Leadership, 1995, 52(4); Phi Delta Kappan, 1995, 76(7). Out of all this controversy, as we begin the $21^{\text {st }}$ century comes an increased recognition of the inevitability and, less so perhaps, the necessity of significantly greater inclusion of students with challenging learning needs in general schools and classrooms (Andrews \& Lupart, 2000; Lloyd, 2000; Lupart et al., 2002). As Schrag (1993) astutely pointed out,

\footnotetext{
an important measure of the success of school reform will be the extent to which the educational system can align and coordinate its interlocking and interdependent educational, social service, and health components and the extent to which the educational system can improve outcomes for all students, including those with disabilities. (p. 225)
}

\section{Key Features of School Reform}

School change in recent decades has several characteristics that have been consistent or even strengthened by progressive efforts to make schools better. At the core is the fundamental question of the schools' effectiveness in serving the needs and developing the interests and talents of students, especially those who have been relegated to the margins (Wang et al., 1994). The latter concern, of course, has been the driving force and conceptual foundation of special education from the start. Indeed, Keough (1988) has bluntly criticized the efforts of inclusion advocates stating "it is strange logic that calls for the regular system to take over responsibility for pupils it has already demonstrated it has failed" (p. 20). True as it might be, this stance clouds the looming reality that schools have been rigidly welded to the belief that students must fit into the inflexible structures and programs that are made available, and that failure on the part of students to succeed in school is more attributable to the learning problems inherent in these students as opposed to the ineffectiveness and inability of schools to provide appropriate accommodation for the growing diversity of student learning needs. What recent school reforms in both regular and special education have brought to light is that, despite well intentioned efforts over the past two decades, the margins appear to be widening and perhaps more importantly they are beginning to overlap traditional, dual education system parameters, and as a consequence, the public is fast losing confidence in education generally (Lupart et al., 2002). The problems associated with providing appropriate education and instruction for students who cannot cope and do not thrive in the regular education system that once was the primary concern of special educators, has, out of necessity, become the responsibility of all educators.

One major contributor to the perceived decline in the quality of schools may be increases in the proportion of children affected by poverty. Several issues that are interrelated with poverty are urban decay; single-parent households; and membership in racial, ethnic, and/or linguistic minority groups (Carnegie Forum on Education and the Economy, 1986; Glickman, 1998; Kozol, 1991; Levin 1995a, 1995b; Lieberman, 1992). These factors combine to form what is for too many of these children an almost impermeable cap on academic achievement. That is, the personal, social, and emotional problems that arise from poverty contribute to disproportionate student drop-out rates, low student achievement, and school violence (Lieberman, 1992; National Association of Secondary School Principals, 1992; National Commission on Excellence in Edu- 
cation, 1983; Tucker et al., 2002). As a result, members of the middle and upper classes, and even the poor, have grown to believe that the quality of schools has dropped, when in fact schools simply have been asked to provide solutions to a daunting array of social and economic ills without the necessary resources (Goodlad, 1984; Kozol, 1991; Pogrow, 2002).

Goens and Clover (1991), however, asserted that it is dangerous to claim that educators should not be blamed for poor student achievement because of the social context of students' families, adding that this implies that teaching is a futile exercise when, indeed, teachers can influence student achievement levels. Nevertheless, students' social environments, especially that provided by the family, does affect a child's performance in school and in life after school (Bridge, 1978). Thus, it may be quite pointless to set political goals such as "By the year 2000, all children in America will start school ready to learn" (National Education Goals Panel, 1991, p. 4) unless poverty-related and student diversity social issues could have been addressed successfully. However, the probability that North American citizens will be willing to devote increased resources to social service initiatives in the near future is low, given the aging of the so-called baby boomers (Carnegie Forum on Education and the Economy, 1986; Goens \& Clover, 1991; Presseisen, 1985), the growth in power of multinational corporations with reduced interest in local social issues (Bates, 2002), and the possible decline of the public's social conscience (Barlow \& Robertson, 1994).

School reform in the 1980s and 1990s was based to a large extent upon the premise that education should be a competitive activity in which efficiency and measurable outcomes are priorities. Even before 1900, education adhered to an industrial model of organization and adopted principles of efficient scientific management. That alignment of education and business continued throughout the $20^{\text {th }}$ century. During the past decade, the private sector changed in response to more intense international competition and demanded that education adopt a market model or charter model (Cobb \& Glass, 1999) of school governance, complete with decentralized decision-making and competition for students (Murphy, 1991; Phillips, 2001). The rationale given by business-oriented school reformers is that competition among students and teachers will lead to benefits such as greater knowledge and adaptability for both consumers (i.e., students and their parents) and businesses (i.e., schools; Cuban, 1990). However, it is not clear that moving away from stability and predictability and closer to a "third-wave company" style, as suggested by Goens and Clover (1991), will benefit children or ensure national economic success (Aronowitz \& Giroux, 1985; Levin, 1993).

The lobby to have schools adopt a business style of operation often is headed by business people with little or no confidence in the ability of school personnel to adapt to changing conditions in society (Cornett, 1995). Indeed, Kearns and Doyle (1988) claimed that education must be restructured, and particularly, a business focus must occur:

To be successful, the new agenda for school reform must be driven by competition and market discipline, unfamiliar ground for educators. Business will have to set the new agenda, and the objective should be clear from the outset: complete restructuring. (p. 5)

Not surprisingly, this type of assertion raised the ire of teachers, administrators, and school board members (Webber, 1995) and has done little to promote positive school-business relations. The bulk of these reform proposals have been generated from "outsiders," such as government officials and legislators, professors in higher education, and corporate world executives, and ironically the educational "insiders" who must ultimately implement these plans, proposals, and recommendations have rarely been involved in their formulation (Lovitt, 1993). 
Statements that the quality of education is linked directly to a nation's ability to vie successfully with international business competitors apparently are widely accepted (Carnegie Forum on Education and the Economy, 1986; Conference Board of Canada, 2000; Government of Canada, 1991a, 1991b; Levin, 2001a; National Education Goals Panel, 1991). Equally well accepted is the corollary that a highly skilled work force is necessary for a nation to match its international rivals (Murphy, 1991; National Association of Secondary School Principals, 1992). Such claims often are accompanied by appeals to citizens' belief in democracy, liberty, individual worth, and even loyalty to their nation (See Kearns \& Doyle, 1988; National Commission on Excellence in Education, 1983; Presseisen, 1985). It is not an exaggeration to say that there may be elements of ethnocentrism, even xenophobia, in the beliefs and fears of at least a few advocates for school reform. That said, it is important to remember Levin's (2001b) caution that beliefs, founded in fact or otherwise, influence politics and policy and therefore need to be addressed. It is important that educators do not carelessly reject these concepts and belief systems which may have direct bearing on schooling, albeit in a more rational and reasoned formulation, as has been suggested by some leading educational reformers (Meyen \& Skrtic, 1995; Skrtic, 1991).

Along with school reformers' patriotic appeals often comes the implication that the levels of achievement formerly reserved for North America's most able learners now must be reached by virtually all students, teachers, business people, and other citizens. The Carnegie Forum on Education and the Economy (1986) explicitly stated that "people must learn at levels that used to be reserved for high achievers" (p. 20). Others, like the National Association of Secondary School Principals (1992) and the National Commission on Excellence in Education (1983), drew the link between high student achievement and success in the information age, where success apparently was thought to be the accumulation of power and wealth. This assertion, whether or not it is ultimately seen as a viable and predominant thrust for future school restructuring, cannot be blindly adopted without first considering the implications it has for special education (Meyen, 1995). For example, some of the more obvious questions that emerge out of this kind of analysis would include: Will the standards of achievement set be attainable to students with disabilities? Will alternative tests be designed to ensure that students with disabilities are able to demonstrate what they know? and Will students with disabilities be included in national testing, and will the results of their performance be aggregated with the results of non-disabled students? (Meyen, 1995).

School personnel cannot, it seems apparent, promote an overall improvement in students' skills and knowledge without forging stronger alliances with other segments of society. Murphy (1991) correctly pointed out that young people participate in a variety of educational environments besides schools. Furthermore, he cautioned that much of students' non-school learning comes to them directly with little or no explanation by adults. For example, the whole spectrum of the electronic media, an age and socio-economically segregated peer group, part-time work environments, and a plethora of family relationships are all vehicles for learning. In contrast, the formal learning conveyed by school programs and personnel constitutes a relatively weak educational force for many children and adolescents. Murphy went so far as to say that schools may collapse under the concurrent tides of rising public expectations and weakening influence on young people. The only way around the dichotomy may be for schools to form coalitions with business and industry, plus the various communities formed as a result of existing special interests and emerging technologies (Gartner \& Lipsky, 1996; Lipsky \& Gartner, 1989; Murphy, 1991; Presseisen, 1985). School personnel should continue to strive to work closely with the many cultural and advocacy groups that are constantly assuming new forms and being redefined, 
but still influential in the lives of youngsters. To achieve this kind of integrated learning environment, Sizer (1992) said that a "narrow, piecemeal" (p. 28) approach to reform must be avoided. Instead, systemic reform must happen if, as Lieberman (1992) predicted, more students will learn independently and in groups within the context of a problem-oriented curriculum taught by teachers-as-facilitators instead of teachers-as-information-givers. Students, parents, and teachers within this type of school environment would be more free to address truly important, but probably controversial, skills and academic content (Darling-Hammond, 1993), thereby attending to at least part of Gaskell's (1995) caution that schools avoid becoming merely prep schools for postsecondary institutions and avoid reinforcing social hierarchies.

A final, key feature of school reform is the need to bring about greater unity of the existing dual systems of educational service delivery, while maintaining the elements of the competing reform efforts that have been achieved, and that can potentially strengthen and advance the mutual goals of excellence and equity. How to do this is not yet clear, since the bulk of previous efforts have been carried out largely in isolation and without due consideration of the totality of the student population an education system must serve. As Goens and Clover (1991) suggested, much of the current disillusionment can be attributed to the segmentalist, bandwagon attempts of previous reforms in which quick fix, single or partial solutions are put forward as if schools were monolithic, rational organizations. Concepts such as decentralization, student-centred learning, multi-grading, de-streaming, and inclusion abound in current schools; however, these piecemeal efforts soon run into snags. The reality is that schools are complex socio-technical-political institutions that operate within a set framework of legislation and policy to meet the expectations of a diverse and demanding public, which are channeled through the efforts of locally elected school trustees. This very complexity makes it essential that school change cannot be simply achieved through school renewal or school restructuring, as it has been interpreted in the past. Rather, Goens and Clover (1991) called for large-scale systemic change in the form of dynamic and continuous school transformation. By this, they meant that changing the character or condition of an enterprise completely or essentially and "altering the nature and purpose of education in light of changing conditions and environment" are the goals of transformation (Goens \& Clover, 1991, p. $10)$.

Special education serves as an important reminder of the dangers inherent in piecemeal and/or pull-out solutions for some, and even most, but not all of the student population that must be served in our schools (Kauffman \& Hallahan, 1993). Meyen (1995) poignantly suggested that "most, perhaps all of what special education is today reflects what schools are doing in response to legislation. Some of these responses are perceived as sound educational practices; others stem from the consequences of noncompliance" (p. 93). This is primarily evident in the U.S. federal legislation of the Education of the Handicapped Act and the Individuals with Disabilities Education Act, which includes provisions for due process, free and appropriate public education, individualized education programs, and nondiscriminatory testing. In Canada, where educational legislation and policy is determined at the provincial level, a recent, comprehensive analysis revealed similar progress with respect to legislation pertaining to non-discrimination and access, and, to a lesser degree, parental participation, service delivery, and identification and placement (Smith \& Foster, 2000). The gains that many students who are educationally challenged currently benefit from have arguably come about as a result of rules and regulations that schools are mandated to comply with. However, the problems that this kind of intervention on behalf of some of the school population creates may work against the purposes it seeks. Smith's (1994) survey, for example, shows us that there are huge discrepancies in the protections that the legislative provisions offer from one province to the next. And, as countless (not to mention costly) litigations 
and student appeals have indicated, even the most contemporary and advanced legislation does not automatically translate into best possible practice. In this regard, Smith (1994) reminded us that education is not provided by governments or school boards, but by teachers and other personnel in thousands of classrooms throughout the country and it is the day-to-day commitment and competence of these individuals that ultimately determines the extent and quality of education students receive. In a similar vein, Meyen (1995) cautioned that current special education realities, such as labelling students in order to receive an appropriate education and parental monitoring to ensure compliance, may not be the "ideal" way to accommodate the needs of students who are educationally challenged.

Finally, we must be cognizant of the impact of special education reform demands on the general education system. Fuchs and Fuchs (1994) warned that the recent demands of radical reformers for full inclusion of students who are severely and/or multiply handicapped may indeed have caught the attention of general education that the earlier, more conservative REI movement sought. However, the effects might be to irrevocably spark general educator resistance to inclusion, and perhaps even reverse the inroads that have been made into the general education system for children with mild and moderate disabilities (Lupart, 1998). Could we not think of better ways to harness the incredible energies and resources it now takes to uphold these clashing, seemingly negative pathways of resistance within the special education and general education community and together create schools where "special education programs no longer would differ from 'plain good' instructional practice” (Meyen, 1995, p. 93)?

Clearly, we have reached a significant crossroads in education change. Momentum from the divergent pathways of education restructuring must be captured and redirected in ways that ensure the educational needs of all students - disabled, poor, cultural minority, disadvantaged, gifted, and even the mythical regular student-will be appropriately served. The challenge is perhaps greater than any other time in our century long public education history, and the uneasiness it has generated in our schools and our society is palpable. Rather than becoming paralyzed by the conflicts and uncertainties change engenders, North American educators have in their hands a timely opportunity to reinstate their laudable goals, purpose, and contribution to the society and the world. Also, unlike any time before, we have the knowledge base, expertise, and research to create the educational culture and communities that we all seek. It is a time for reflection, collaboration, and renewed faith in our teachers and students who are the critical participants in meeting this challenge. With the ultimate goal of providing a free and appropriate public education for all students as our shared, collective challenge, we can begin to sort through the various obstacles that must be addressed and begin to expand the likely fostering conditions that are already being practiced in a few schools and regions across the United States and Canada.

\section{Obstacles to School Reform}

There is a popular belief that school reform initiatives have been almost uniformly unsuccessful in bringing about significant longitudinal change close to what reform proponents wanted (Elmore, 1978; Georgiades \& Keefe, 1992; Goodlad \& Lovitt, 1993; Lipsky \& Gartner, 1989). It must be acknowledged that some restructuring mandates have been successful. However, this was the case only when necessary adaptations of both the mandate and the school culture are possible (Berman, 1981; M. W. McLaughlin, 1978; Meyen \& Skrtic, 1995; Porter \& Richler, 1991; Villa, Thousand, Stainback, \& Stainback, 1992). Unfortunately, top-down reform efforts, which are usually popular with legislators (Powell et al., 1985; Taylor, 2001), seldom have allowed much latitude for teachers and administrators. The result too often has been a superficial adoption of the reform with insignificant adjustments to school practice. Even suggestions that 
truly aversive economic sanctions be employed to force educators to do the bidding of legislators (Mann, 1978) have failed to erase the need for site adaptation of reform packages. It seems obvious to impute that without a significant balance of bottom-up and grassroots change initiatives, any top-down measure is doomed from the start. In fact, it may be the case that the disproportionate power of the few in the upper echelons of educational decision making and governance over what gets targeted for change and the conditions under which it is to be done, has created more obstacles to meaningful, significant reform by overburdening the teachers and administrators who must make it work in the schools. Following the passage of PL 94-142 in the United States and policies with similar clauses in Canadian schools, for example, many educators complained of the many, additional hours spent in preparation of individualized educational programs and, afterward, in monitoring and documenting the specialized services and programming that the integration of students with exceptional learning needs required by law. At issue is the very real concern that these requirements detract significantly from the teacher's overall planning time and might actually diminish the quality of actual in-class teaching and instruction for regular and special education children.

Two other obstacles to restructuring are the stronghold of the status quo (Sizer, 1984) and a demoralized teaching force (Aronowitz \& Giroux, 1985). As well, the tendency of policy makers to seek quick solutions to problems (Fullan, 2001; Fullan \& Miles, 1992) and to ignore the cultural complexities of schools in relation to their communities (Goens \& Clover, 1991) has reinforced the image of schools as inflexible, ritualistic environments. However, Maxcy (2002) noted that "The professional educator engages in good work in a regular and systematic way. Professional practice is just that, a kind of repetitive performance marked by moral and ethical indicators" (p. 6), thereby challenging the notion that change can occur quickly.

Advocates for school restructuring have articulated a series of seemingly conflicting goals. Clearly, it is difficult for school-based management and national goals to be addressed simultaneously. Equally problematic are the concepts of teacher professionalism versus standardized curricula, academic rigor versus international achievement test comparisons (Murphy, 1991), student excellence and equity (Skrtic, 1995), and perceptions of students as clients versus shared responsibility for learning (Webber, 1995; V. Bohac Clarke, personal communication, March 30, 1994). In particular, claims from business people that students and/or their parents should be treated as customers or clients (Kearns \& Doyle, 1988) are strong examples of the misapplication of a business paradigm to teaching and learning. An extension of the notion of "students as clients" is the pressure on schools in some regions of the world to generate their own revenue thereby creating the opportunity for some benefits, such as additional infrastructure and teachers, but also the possibility of concerns about equity, efficiency, a distraction from teaching and learning, and corruption $(\mathrm{Ng}, 2001)$.

Implicit in the student-as-customer paradigm is the idea that educators carry the bulk of the responsibility for ensuring students' academic success. Ignored is the fact that others, such as curriculum developers, parents, politicians, students, and teacher educators, also are major contributors to the success or failure of students to learn. Also ignored in the student-as-customer perspective is the fact that some young people are not interested in learning or the application of knowledge, or may not be capable of benefiting from the traditional curriculum that is offered. In fact, some students attend school because the law requires it and because their friends are at school; students who do not want to learn are not clients (Murphy, 1991; Powell et al., 1985). Furthermore, the uniform standards exacted by standardized curricula and tests virtually preclude the treatment of students as customers with special needs and interests (Elmore, 1990). For these reasons, restructuring efforts must move beyond simple, quick-fix agendas (Harris, 2001; 
Holmes Group, 1986). Touted solutions must be sufficiently powerful and enabling for the entire school community, particularly the teachers and students who will have the most central role in making them work, and must simultaneously address the excellence and equity issues that reform proponents have raised.

Over-reliance upon standardized testing as a measure of school quality is another major obstacle to the improvement of schools. Beyond the issues of technical adequacy of the tests and procedures used, and the socioeconomic (and ability) disparities they reveal, is the fact of significant (though rarely talked about) costs these accountability programs incur (Nagy, 1995). Standardized tests are designed to measure only part of school life (Sizer, 1984). A more complete picture can be gotten by adding information garnered through parent and student surveys, interviews, observations, and case studies, for example. Undue faith in standardized tests can lead to cheating by a small proportion of students, and even teachers (Schlechty, 1990a), who feel that less than optimal performances are too costly to bear. Moreover, the standards set may be impossible, if not inappropriate, for a significant proportion of the school population (Meyen, 1995). While there may be great value in accumulating good performance information for educational decision making, Nagy (1995) warned that the already substantial costs for this process pale in comparison to the costs of changing the system in response to the information once you have it. Importantly, Stiggins (2002) highlighted the significance of "balancing assessments out and for learning" (p. 763) so that a focus on teaching and learning is maintained.

Elmore (1990) challenged the assumption that education systems are resistant to change. In fact, he suggested that the very responsiveness of educators to a host of diverse accountability pressures has made it difficult to maintain a coherent framework for teaching and learning. The irony of the situation is elucidated by Nagy (1995) who says that there can be little argument that schools have responded to a myriad of societal demands which has positively brought new elements such as AIDS awareness, parent education, anti-violence education, second language education, physical education, and so forth into our schools. Each new element, however, reduces the time we can spend on the traditional "basic" curriculum, and yet our progress as measured in most accountability programs is focused on student achievement in the "basics." Furthermore, Elmore (1990) predicted that the breadth of the reform movement will add to the many expectations placed upon schools, to the point that the effectiveness of restructuring programs will be minimal. Similarly, Weatherley and Lipsky (1978) and Bottery (2002) feared that by asking for so much, proponents of reform achieve very little.

In 1985, Presseisen cautioned policy makers to avoid implementing only those reforms that were low cost because that would result in little meaningful change in schools. Throughout the next decade, others made similar pleas (Carnegie Forum on Education and the Economy, 1986; Cornett, 1995; Murphy, 1991; National Association of Secondary School Principals, 1992), but to little avail. Similar cautions have been raised by inclusion advocates of children with exceptional learning needs, who fear that the movement will be inappropriately used by school administrators as a quick way to save funds by simply closing down special education classrooms and placing students into the regular classroom without the necessary preparation of regular teachers and without making provisions for the continuation of appropriate services (Andrews \& Lupart, 2000; Goodlad \& Lovitt, 1993; Lupart, 1998). Few school districts, states, or provinces were willing and able to support school improvement programs with adequate personnel, time, professional development, or materials. This supports the contention that educators are willing to change but too often reach the point where they cannot "do more with less" (Barth, 1990, p. 12).

Another important and potential obstacle to school reform is the prevailing views on teaching. Two competing perceptions of teaching have been part of school restructuring throughout 
this century. From one perspective, teaching is viewed as simple, routinized, and technical, meaning that anyone with a reasonably good general knowledge can teach (Darling-Hammond, 1993). This conception of teaching probably developed when teaching was a short-term occupation for women prior to marriage or for men using teaching as a stepping stone to other professions (Holmes Group, 1986). Within this paradigm, change can be accomplished through a system of rewards and sanctions. An alternative view is that teaching is an intricate process involving a multitude of observations, interactions, and decisions (Darling-Hammond, 1993; Maxcy, 2002). Change under this rubric is achieved through an understanding of school culture, moral and ethical practices, group theory, student diversity, professional development, and teacher empowerment.

Rowan (1990) supported the perception of teaching as a complex, professional endeavor when he asked, "Why bother to seek out and hire bright principals and teachers, and then keep them on a short leash?" (p. 10). Unfortunately most school reforms in North America have been based on the assumption that teaching is a relatively simple, mechanistic process (Skrtic, 1991, 1995). Thus, a basic paradigm shift is necessary. More policy makers must understand that attention needs to be given to collegiality, group development processes (Lieberman, 1992), personal values (Goens \& Clover, 1991), and democratic principles (Skrtic, 1995) if school reform is to become more successful. Finally, the second, more organic view of teaching implies that policy makers should assume that most teachers are professional and altruistic; consequently, policy makers also should rely more upon theory and research than upon ideology and politics when making decisions (Astuto \& Clark, 1992). Moreover, policy makers would not misinterpret educators' need for time to understand and adapt to change as "resistance" (Fullan \& Miles, 1992).

Finally, one of the most significant obstacles to successful school reform is the lack of evidence to link changes in school governance to economic competitiveness (Hawley, 1978; Levin, 1993, 2001a) or even student learning outcomes (Murphy, 1991). In fact, governance changes such as school-based management actually may reduce the quality of teaching because the time teachers must put into meetings and committee work detracts from the attention teachers give to their classroom duties (Dimmock, 1993).

The obstacles we have identified are not insurmountable, and may in fact be directly attributed to a lack of perceptual and conceptual consensus among those who influence and mandate education change and those rooted in the school culture. Before moving to a discussion of the conditions to foster successful school change, it is important to consider the evolving roles of those most centrally connected with the school culture.

\section{Evolving Roles}

Increased parent involvement in educational decision making has been a major goal for proponents of school restructuring. In particular, decentralization of authority was seen as a means to achieving greater parent involvement. As well, devolution of control was deemed to have many other advantages (Cuban, 1990; Murphy, 1991). Decisions would be made by people with knowledge of the local community rather than by bureaucrats or politicians operating from afar. Change would be easier to implement, and competition among schools would promote creative growth impossible within the perceived monopoly of education. The concepts of decentralization and parent involvement have resulted in the implementation of school councils, charter schools, and site-based management practices in Britain and several other English speaking countries, such as Australia, New Zealand, the United States, and Canada. Interestingly, decentralization fit well with the educational paradigm promoted by business organizations like the Conference Board of Canada (M. A. McLaughlin, 1992). Parental involvement and support in 
special education has been a valued and time-honoured tradition (Turnbull \& Turnbull, 1997). Much of what has been achieved in the way of special and/or gifted education provisions in the schools has come about through the unstinting efforts of parents and related parent advocacy groups, and when special educators undertook their search and struggled to find new ways of meeting the individual needs of their students, parents were often their most knowledgeable source and willing collaborators (Andrews \& Lupart, 2000). The experience that has evolved out of this fruitful partnership may be one of the key contributions that special education might bring to a more unified educational system.

Efforts to implement the decentralization of authority continue (Webber, 1995); however, some have cautioned against viewing decentralization and parental involvement as cure-alls (Astuto \& Clark, 1992; Bridge, 1978; Goens \& Clover, 1991; Murphy, 1991). At its worst, decentralization can simply move bureaucratic power and control from the central office level to the school principal, allow tyrannous school administrators to exclude teachers and parents from decision making, and students' voices to be denigrated. But negative results such as these are not certainties and some schools have found that site-based management, for example, has resulted in greater responsiveness to student needs and closer school-community relations.

Additional cautions abound. Bridge (1978) noted that it is easier to get parents to rally around points of concern than it is to get them to assist in the daily life in schools. He also recognized that there is no consensus among parents about how schools should operate. Further, the willingness of parents to become involved in schools depends partially upon issues of gender. That is, most parents involved in schools as volunteers and school council members tend to be women; men usually stay removed from schools unless a crisis arises or until a major decision about their children must be made. Bridge (1978) and Murphy (1991) also observed that the higher the socioeconomic status of the family, the more knowledgeable parents are about educational issues. However, Weatherley and Lipsky (1978) stated that parent involvement does not ensure that parents' interests prevail. Even well informed parents may succumb to pressures exerted by teachers and principals. But clearly, the characteristics of students' families have implications for the effectiveness of parent involvement in decision making and for the responsibility educators have for keeping parents informed about school issues. Finally, Elmore (1990) and Murphy (1991) both highlight the inherent contradictions in empowering members of school communities. That is, decentralization may appeal to parents, teachers, administrators, and students for entirely different reasons, leading each group to expect its power to increase at the expense of the others. A striking example of this problem can be seen in the current opposing stance of full inclusion advocates for students with severe and profound handicaps and interest groups representing students with learning disabilities and high ability who are generally wary of most inclusion efforts. Full inclusion is perceived as a major threat to the erosion of hard-fought special education services they value most.

Teachers often became demoralized as school reforms of the 1980s and 1990s were introduced. To some, low morale was interpreted as teachers being ineffectual in initiating and carrying out change. According to this view, teachers were resistant and noncompliant, which meant major structural reforms had to be forced upon the educational community (Goens \& Clover, 1991). In other words, teachers were the problem that had to be corrected by legislators who too often did not value teachers' work (Goodlad, 1984; Lieberman, 1992; Webber, 1995). Unfortunately, the school reform literature and news media are replete with references to the inability of schools to change policies and practices (Cornett, 1995).

Many who would force change upon the teaching profession state that education is in a state of crisis. However, the crisis could be the result of policy makers ignoring the need to in- 
volve practitioners in the planning of reforms and to provide educators with sufficient resources to get the job done (Holmes Group, 1986). Rather than being treated by those with political power as partners in the school improvement process, teachers often have "difficulty getting these people's attention" (Sizer, 1984, p. 219). Another, possibly even more debilitating problem is the inherent professional isolation of teachers in the traditional school practice of one teacher working with large groups of students in separate classrooms. For too many of our colleagues within the profession, there are only minimal opportunities to share the excellence and expertise that teachers are demonstrating every day in countless classrooms across North America. Smith and Scott (1990) have suggested that the fact of teacher isolation may be a critical factor in perceived teachers' resistance to change in general and more specifically in the response to recent inclusion initiatives. They noted that "under the best of circumstances, change imposed from (or even suggested by) the outside can be viewed as threatening. And apprehensions about change are reinforced when one must face that change alone" (Smith \& Scott, 1990, p. 10). Students are the losers in this type of professional disenfranchisement in which little recognition is given to the ability of teachers to make a government or school board policy as successful as teachers and policy makers would like it to be (Andrews \& Lupart, 2000; Hawley, 1978; Weatherley \& Lipsky, 1978).

Principals and superintendents are also major players in the implementation of school reform. They determine the degree to which restructuring initiatives are supported (Georgiades \& Keefe, 1992; M. W. McLaughlin, 1978; Moore, George, \& Halpin, 2002). Importantly, administrators do not have to actively oppose a policy in order to ensure its non-implementation; all that is required to scuttle a political mandate is an absence of moral support from principals and/or superintendents, even within the context of decentralized decision making (Murphy, 1991).

Parents also possess the power to determine the success or failure of school and district policies (Bridge, 1978). Therefore, it is incumbent upon both parents and educators to collaborate on restructuring plans. Both groups must know what is expected of them and be involved in important rather than trivial decisions. They must allow themselves time to access and understand the information that is needed to make sound decisions. They also must focus upon constructive approaches to problem solving, despite the fact that proactive strategies take more time and effort than destructive actions. Furthermore, parents and educators should recognize that each school's readiness to move forward is different (National Association of Secondary School Principals, 1992). That means there are no recipes for reform that fit all school communities (Sizer, 1992).

\section{Conditions for Successful Change}

There never has been a time when governments' educational policies could be understood in isolation from practices in schools (Elmore, 1978). However, the history of school reform in North America has been predicated upon the assumption that when federal, state, provincial, or local politicians institute policies then the behaviours of students and teachers will automatically change. The recurring cycle of political mandates, increased public expectations, cooptation at school and community levels, public disappointment, and new mandates must be broken. Reform agendas have, for the most part, been formulated by individuals and groups outside the education discipline and outside the schools and the communities where real change must take effect. Consequently, many reforms are premised on the assumption that everything that is wrong about today's schools is due to poor quality teachers and teaching and, as such, they simply are not helpful. The way to correct this pattern, according to Murphy (1991), is to quit believing, in the face of much evidence to the contrary, that reformatting the governance structures of schooling will change anything of substance. Instead, restructuring should focus on teaching and learning. 
Teachers are the primary mediators of instruction and learning, and any change that results in more, if not all, students achieving their full learning potential will ultimately be a function of their commitment, expertise, and practice. Future direction in school transition must therefore be predicated on the decades of experience and expertise that form the basic foundations of our education systems: from the preparation of future teachers to the discipline, to the day-to-day and year-to-year school operations, and to the ongoing professional development of teachers as they journey from novice to expert. Surely it makes good sense to place those at the centre of the teaching and learning process at the very centre of school change efforts (Andrews \& Lupart, 2000; Levin, 2001a). That means successful reform should begin with groups of teachers, students, parents, administrators, and community members identifying how learning can occur best for different types of young people and then building the educational infrastructure that promotes that learning.

This is not to suggest that outside concerns and policy mandates have no place in school reform. What must be recognized more clearly is the gap between public perception and reality (Nagy, 1995). Over the course of this century society has changed dramatically and the expectations of society for our schools have mounted steadily. Too much attention has been given to what schools are not doing and too little attention has been given to what schools have accomplished: higher than ever levels of literacy and achievement, a markedly expanded curriculum, a greater proportion of students attending school and completing high school, and professional training standards that surpass all previous decades. Recent concerns regarding the preparation of our students for life lived in the 21 st century are the concerns of us all, and certainly they need to be raised and conveyed to the educational community. However, these concerns should not be addressed without, at the very least a balance of input from the very individuals who must effect these changes and who, along with students, are affected by them most. Indeed, we should instead seek greater alignment of the various federal, state and/or provincial, and local community efforts, with the ultimate development and success of our students first and foremost as our common goal (Lupart, 1998).

Next, reform must be based upon clear guidelines for change derived from theory and research (Astuto \& Clark, 1992; Fullan \& Miles, 1992; Goodlad, 1984; Maxcy, 2002; Murphy, 1991). Change is implemented by individuals in specific schools. Therefore, inflexible, checklistbased mandates almost certainly are doomed before politicians vote on them. Change is complex and its success uncertain, which means that a climate of mutual trust and respect is imperative if there is to be any chance of successful reform. Every individual involved should feel personally responsible for an innovation. Change requires resources; efforts to implement change on the backs of already overburdened teachers or parents stand little chance of success. Anxiety, confusion, and problems can be counted on to accompany change. Contemporary education research, theory, and knowledge base is more extensive and advanced that ever before, and within recent years, developments within the field have burgeoned. However, much more is known about successful teaching and learning than we see in actual practice. Therefore, obstacles must be treated as opportunities to learn and grow instead of insurmountable barriers. Successful change rarely occurs quickly, so careful planning and patience are needed. Finally, school reform must emerge from a thorough understanding of each school's unique culture. Reformers must work within the powerful parameters imposed by the beliefs and values held by members of local schools and communities.

Sizer (1984) proposed that schools should be restructured in accordance with several principles. He stated that school programs and services should be reduced to manageable levels and focused on clear and simple goals. He believed that school structures should be kept flexible to 
allow for varied rates and styles of learning, student groupings that are independent of age, and reduced workloads for teachers. Lieberman and Miller (1990) complemented Sizer's (1984) proposals by stating the need for supportive work environments for students and adults, strong partnerships and networks both in and out of schools, critical analyses of curricula and teaching strategies, and recognition of the importance of parent and community participation in schools. The recommendations of these general education reform leaders are no different from what reform leaders in special education and gifted education are calling for, though the provision of a free and appropriate education for all students is their top concern (Andrews \& Lupart, 2000; Goodlad \& Lovitt, 1993; Meyen \& Skrtic, 1995). To this end, Andrews and Lupart (2000) outlined several themes to guide future educational transition toward inclusion including a preventative emphasis over labelling and separate placement, capturing the elements of known effective schools, teachers as models of lifelong education, children-centred education over program or teacher-centred education, and moving from teacher isolation to collaboration.

Successful reform requires courageous, altruistic, astute, and sustained leadership (Barth, 1990; Schlechty, 1990b; Sergiovanni, 1992). Those behaviours must be modeled by a school's formal leaders and by others within the school community, including teachers, students, parents, and central office personnel. Shared leadership can lead to successful, institutionalized change that is not dependent upon the charisma or power of specific individuals. However, the community context of shared leadership may require constant reinventing of communication, authority, and responsibility structures. Educational leaders and learners who are able to form genuine learning communities may become able to exhibit behaviours that are truly proactive and morally defensible. At their best, communities of leaders and learners would be guided by the expectation that every person will strive continually to grow and improve, regardless of role or cognitive ability. This would occur in an environment in which the only failure guaranteed to provoke outrage is to give up on learning.

High quality staff development is the key to successful and sustained innovation in schools (Astuto \& Clark, 1992; Darling-Hammond, 1993; Davis, 2001; Murphy, 1991; Tomlinson, 2001). It should be expected that participants will not have all of the skills and knowledge they need to implement necessary changes and they must have access to appropriate theory, materials, and people. Indeed, supportive staff development can help participants learn to thrive in the uncertain conditions that accompany change. Effective staff development can lead to what Goodlad (1984) called "the capability to effect improvements [which] is more important than effecting a specific change" (p. 282). Moreover, Skrtic (1995) argued that the challenges that a diverse inclusive educational community entails are the very elements that are needed to create schools that are excellent and equitable.

Many educational leaders have advocated the merging of regular and special education systems into a unified or coordinated system of educational program delivery as an essential first step toward meaningful school transition (Andrews \& Lupart, 2000; Lipsky \& Gartner, 1989; Meyen \& Skrtic, 1995: Stainback et al., 1989). Wang (1990) called for the application of all forms of extant knowledge as a central focus for all school change. Implicitly this means that inclusive education cannot be simplistically achieved by returning students with exceptional learning needs to an unchanged general education system. The knowledge base that has been separately developed in segregated special education classes needs to be synthesized into the broader general education system. Specialized forms of instruction and assessment coming out of special education classes need to become commonly practiced in general education classes to ensure that the learning needs of a more diverse student population are met. In an interview on inclusion (O’Neil, 1994), Mara Sapon-Shevin distinguished between a "continuum of place- 
ments" and a "continuum of service" for students with special educational needs. The former perspective tends to support general education resistance to school restructuring (i.e., maintaining the status quo) whereas the latter supports continued specialized provisions such as speech therapy and at the same time meets the special educational needs within the regular classroom. Schrag (1993) added to this conception by asserting that "special education must be viewed not as a 'place' but rather as a set of instructional and curricular supports intended to provide a broad array of better student outcomes" (p. 205). With respect to the traditional separation of curriculum in regular and special education, here too educators are to be encouraged to seek out ways of more effectively synthesizing curriculum options and to provide sufficient differentiation of learning opportunities. Pugach and Warger (1993) noted, "the curriculum that special education has enacted over the years, and the whole school context in which special education takes place, have interacted to disenfranchise students from access to a broad, rich and meaningful education" (p. 135). More than any other factor, successful transformation of the schools will depend on the willingness of special and regular education teachers to assume full responsibility for the entire student population within a given community. Artificial barriers created through arbitrary divisions of special, gifted, and regular education and traditional grade-by-grade and subject-bysubject service delivery need to be replaced with more flexible, student-centred delivery arrangements. As Meyen (1995) correctly asserted, children should no longer have to be labeled to receive an education that is appropriate to their learning needs.

Finally, successful change in school requires planning for both short and long term effects. Short-term considerations include time for educators and community members to discuss and understand what needs to be done to improve teaching and learning (Andrews \& Lupart, 2000; Murphy, 1991; Yewchuk, 1996). Some work in the area of collaborative consultation indicates this may be an especially powerful means of merging special and regular educator expertise (Idol, 1996) and for consolidating educator expertise at the general school level (Smith \& Scott, 1990; Wang, 1996; Wong, 1996). For this to happen, all participants need time to acquire necessary skills and knowledge. At this point, policy makers and community members may need to be reminded that long-term success precludes early summative evaluations (Bridge, 1978; Sizer, 1992). In fact, assessments of programs implemented prematurely because of pressure put on educators to achieve a great deal within a short time, are virtually certain to promote failure of innovations. Politicians and administrators cannot expect to achieve great impacts between elections.

\section{Conclusion}

Change is a central theme in schools throughout North America today. It has taken the greater part of the century for the current public education system to evolve and up to the early 1980s there was general satisfaction with schools and student learning. Currently, nearly every aspect of traditional schooling has become a target for criticism, or at least this is how it seems for those most closely connected with the educational community. Philosophy, curriculum, school organization, teachers and their preparation, financing, and student learning achievement are some of the most predominant areas. Even though there has been a virtual flood of activity as has been the response to these mounting criticisms, the general perception is that schools have largely remained the same as always. Our analysis suggests that too much attention has been given to top-down initiatives driven by faulty public perceptions, economic and business world prescriptions, and piecemeal, quick-fix political and governmental policies and legislation. Elmore (1987) talked about deep cycles of optimism and pessimism/peaks and valleys. Reform literature shows that these cycles do not in the end have much impact on the "way teachers teach, 
the way students are expected to learn, and the way knowledge is defined in schools" (p. 61). For significant, meaningful change to occur, we must focus our attention on the teachers and students first and then move outward.

Murphy (1991) advanced the view that schools are moving away from a mechanistic, production- and efficiency-driven system toward a market-sensitive system:

The mass production perspective of the past is giving way, grudgingly, to more customized technologies. Mechanistic forms of management and control are beginning to be replaced by more organic forms of organization. These restructured schools, in their incipient stages of development, are characterized by greater decentralization, a higher degree of internal differentiation, and more autonomous work units. There is less rigidity to internal structures, responsibilities are less firmly anchored to specific roles, and control and coordination have less to do with hierarchical authority than with cooperative work efforts. (p. 14)

It seems clear that traditional school structures of control and competition need to be transformed into conditions of cooperation, collaboration, creativity, and care. Schlechty (1990b) put it this way: "restructuring requires, more than anything else, a commitment to the proposition that the school's most important resource is the human resources the system employs" (p. 110).

The central role of classroom teachers in making school transition work is vividly apparent in the McLaughlin and Marsh (1979) article on the Rand study of staff development and school change. The key attributes to emerge from this analysis of several federally funded school change projects included years of experience, verbal ability, and sense of efficacy. A curvilinear effect of professional peaking after 5 to 7 years was typically followed with a decreasing interest in professional growth and teaching innovation. McLaughlin and Marsh suggested that this 'calcifying' effect could be attributed to the way schools are managed and the way professional development activities are provided for staff. The second characteristic, verbal ability, was directly and significantly related to student achievement, as opposed to student affective development. The most powerful characteristic, and one that has direct implications for creating inclusive schools, was a teacher's sense of efficacy in believing in his or her ability to help all students, even the most difficult or unmotivated. Teacher attitudes concerning their own professional competence is the single most important element in teacher effectiveness. The Rand study findings confirm many recent report recommendations to engage teachers directly in school-related problem solving and solution finding; to encourage teachers to use these opportunities in an adaptive and heuristic manner; to recognize that professional development is a long-term, non-linear process; that it should be intrinsically tied to the on-going program building process in schools; and that professional growth is critically influenced by school and system organization. Lieberman (1990) summarized the current educational change themes as "the creation of community in schools, the struggle to understand and develop the use of such ideas as commitment, incentives, colleagueship and leadership, and the desire fundamentally to rethink how schools can change" (p. XI).

These are, we think, the critical elements that need to shape school transformation efforts in schools today. Some of this is already happening in schools and pockets of schools throughout North America, and the immediate task for all educators is to become more informed about what is working and to begin to incorporate and adapt these ideas in ways that success will be achieved in our own schools and learning communities.

At the same time we must be mindful of the fact that children with educational challenges have had to rely on legislated policies and mandates to even be included in our schools. This is not right. All teachers need to be concerned about meeting the needs of all students within their educational communities. Presseisen (1985) asserted, "the job of schools is to educate and social- 
ize, not to be sorting grounds for haves and have-nots or knows and know-nots" (p. 101). The challenge is clear. Regular and special educators are the professionals who must make school transformation reflect excellence and equity. To achieve this goal all teachers need to be fully aware of and informed about the learning needs of all students, and ultimately mindful of their role and responsibility in achieving student success. This is not an easy goal to accomplish, considering the traditional separation of regular classroom teachers and special education teachers. It is, however, and will continue to be a significant barrier to real educational transformation unless this goal is met.

\section{References}

Andrews, J., \& Lupart, J. L. (2000). The inclusive classroom: Educating exceptional children (2nd ed.). Scarborough, ON: Nelson.

Aronowitz, A., \& Giroux, H. A. (1985). Education still under siege. Toronto, ON: Ontario Institute for Studies in Education.

Astuto, T. A., \& Clark, D. L. (1992). Challenging the limits of school restructuring and reform. In A. Lieberman (Ed.), The changing contexts of teaching (pp. 90-109). Chicago, IL: University of Chicago Press.

Audette, B., \& Algozzine, B. (1992). Free and appropriate education for all students: Total quality and the transformation of American public education. Remedial and Special Education, 13(6), 8-18.

Barlow, M., \& Robertson, H. J. (1994). Class warfare: The assault on Canada's schools. Toronto, ON: Key Porter.

Barth, R. S. (1990). Improving schools from within. San Francisco, CA: Jossey-Bass.

Bates, R. (2002). Administering the global trap: The role of educational leaders. Educational Management and Administration, 30(2), 139-156.

Berman, P. (1981). Educational change: An implementation paradigm. In R. Lehming \& M. Kane (Eds.), Improving schools: Using what we know (pp. 253-286). Beverly Hills, CA: Sage.

Bliss, J. R., Firestone, W. A., \& Richards, C. E. (1991). Rethinking effective schools: Research and practice. Englewood Cliffs, NJ: Prentice Hall.

Bottery, M. (2002). Educational leadership and economic realities. Educational Management and Administration, 30(2), 157-174.

Boyd, W. L. (2000). The "R's of School Reform" and the politics of reforming or replacing public schools. The Journal of Educational Change, 1(3), 225-252.

Bridge, R. G. (1978). Parent participation in school innovations. In D. Mann (Ed.), Making change happen? (pp. 101-119). New York, NY: Teachers College Press.

Bunch, G. (1994). Canadian perspectives on inclusive education from there to here: The passage to inclusive education. Exceptionality Education Canada, 4(3 \& 4), 19-35.

Carnegie Forum on Education and the Economy. (1986). A nation prepared: Teachers for the 21 st century. New York, NY: Carnegie Foundation.

Carnoy, M. (2000). School choice? Or is it privatization? Educational Researcher, 29(7), 15-20.

Cobb, C. D., \& Glass, G. V. (1999). Ethnic segregation in Arizona charter schools. Education Policy Analysis Archives, 7(1). Available online: http://epaa.asu.edu/epaa/v7n1/

Conference Board of Canada. (2000). Performance and potential 2000-2001. Ottawa, ON: Author. Available online: http://www.conferenceboard.ca/e-Library/abstract.aspx?did=256

Cornett, L. M. (1995). Lessons from 10 years of teacher improvement reforms. Educational Leadership, 52, 26-30.

Cuban, L. (1989). The "at-risk" label and the problem of urban school reform. Phi Delta Kappan, 70, 780784, 799-801.

Cuban, L. (1990). Reforming again, again, and again. Educational Researcher, 19(1), 3-13.

Darling-Hammond, L. (1993). Reframing the school reform agenda: Developing capacity for school transformation. Phi Delta Kappan, 74(10), 253-762.

Davis, B. (2001). The Australian principals center: A model for the accreditation and professional development of the principalship. International Studies in Educational Administration, 29(2), 20-29. 
Davis, G. A., \& Thomas, M. A. (1989). Effective schools and effective teachers. Boston, MA: Allyn and Bacon.

Dimmock, C. (1993). School-based management and linkage with the curriculum. In C. Dimmock (Ed.), School-based management and school effectiveness (pp. 1-21). London, UK: Routledge.

Dunn, L. M. (1968). Special education for the mildly retarded: Is much of it justifiable? Exceptional Children, $35(1), 5-22$.

Elmore, R. F. (1978). Organizational models of social program implementation. In D. Mann (Ed.), Making change happen? (pp. 185-223). New York, NY: Teachers College Press.

Elmore, R. F. (1987). Reform and the culture of authority in schools. Educational Administration Quarterly, 23(4), 60-78.

Elmore, R. F. (1990). Restructuring schools: The next generation of educational reform. San Francisco, CA: Jossey-Bass.

Fuchs, D., \& Fuchs, L. S. (1994). Inclusive schools movement and the radicalization of special education reform. Exceptional Children, 60(4), 294-309.

Fuhrman, S. H. (Ed.). (1993). Designing coherent education policy. San Francisco, CA: Jossey-Bass.

Fullan, M. G. (2001). The new meaning of educational change (3rd ed.). New York, NY: Teachers College Press.

Fullan, M. G., \& Miles, M. B. (1992). Getting reform right: What works and what doesn't. Phi Delta Kappan, 73(10), 744-752.

Gallagher, J. J. (1991). Educational reform, values and gifted students. Gifted Child Quarterly, 35(1), 12-19.

Gartner, A., \& Lipsky, D. (1996). Serving all students in inclusive schools: Contrasts in Canadian and US experience. In J. Lupart, A. McKeough, \& C. Yewchuk (Eds.), Schools in transition: Rethinking regular and special education (pp. 60-80). Toronto, ON: Nelson Canada.

Gaskell, J. (1995). Secondary schools in Canada: The national report of the Exemplary Schools Project. Toronto, ON: The Canadian Education Association.

Georgiades, W. D., \& Keefe, J. W. (1992). A second-generation design: The learning environments consortium. In National Association of Secondary School Principals (Ed.), A leader's guide to school restructuring: A special report of the NASSP Commission on Restructuring (pp. 15-22). Reston, VA: Author.

Glickman, C. D. (1991). Pretending not to know what we know. Educational Leadership, 48(4), 4-10.

Glickman, C. D. (1998). Revolution, education, and the practice of democracy. Educational Forum, 63(1), 1622.

Goens, G. A., \& Clover, S. I. R. (1991). Mastering school reform. Needham Heights, MS: Allyn \& Bacon.

Goodlad, J. I. (1984). A place called school: Prospects for the future. New York, NY: McGraw-Hill.

Goodlad, J. I., \& Lovitt, T. C. (1993). Integrating general and special education. New York, NY: Merrill.

Government of Canada. (1991a). Learning well...living well. Ottawa, ON: Ministry of Supply and Services.

Government of Canada. (1991b). Prosperity through competitiveness. Ottawa, ON: Ministry of Supply and Services.

Haberman, M. (2000). Urban schools: Day camps or custodial centers? Phi Delta Kappan, 82(3) 203-209.

Hallahan, D. P., \& Kauffman, J. M. (1991). Exceptional children: Introduction to special education (5th ed.). Englewood Cliffs, NJ: Prentice Hall.

Harris, A. (2001). Holding the fort? Leading in improving schools in difficulty. Management in Education, 15(3), 21-23.

Harris, A., \& Chapman, C. (2002). Democratic leadership for school improvement in challenging contexts. International Electronic Journal for Leadership in Learning, 6(9).

Hawley, W. D. (1978). Horses before carts: Developing adaptive schools and the limits of innovation. In D. Mann (Ed.), Making change happen? (pp. 224-260). New York, NY: Teachers College Press.

Hepburn, C. R. (1999). The case for school choice: Models from the United States, New Zealand, Denmark, and Sweden. Vancouver, BC: The Fraser Institute.

Holmes Group. (1986). Tomorrow's teachers. East Lansing, MI: Author.

Idol, L. (1996). Collaborative consultation and collaboration in schools. In J. Lupart, A. McKeough, \& C. Yewchuk (Eds.), Schools in transition: Rethinking regular and special education (pp. 220-244). Toronto, ON: Nelson Canada. 
Johnson, D. W., Johnson, R. T., \& Holubec, E. J. (1986). Circles of learning: Cooperation in the classroom. Edine, MN: Interaction Book Co.

Kaminsky, J. S. (2000). The pragmatic educational administrator: 'Local theory,' schooling, and postmodernism reviled. Leadership in Education, 3(3), 201-224.

Kauffman, J. M. (1981). Historical trends and contemporary issues in special education in the United States. In J. M. Kauffman \& D. P. Hallahan (Eds.), Handbook of special education (pp. 3-23). Englewood Cliffs, NJ: Prentice Hall.

Kauffman, J. M., \& Hallahan, D. P. (1993). Toward a comprehensive delivery system for special education. In J. I. Goodlad \& T. C. Lovitt (Eds.), Integrating general and special education (pp. 73-102). New York, NY: Macmillan.

Kearns, D. T., \& Doyle, D. P. (1988). Winning the brain race: A bold plan to make our schools competitive. San Francisco, CA: The Institute for Contemporary Studies.

Keough, B. K. (1988). Improving services for problem learners: Rethinking and restructuring. Journal of Learning Disabilities, 21, 19-22.

Keys, W. (1997). What do international comparisons really tell us? International Electronic Journal for Leadership in Learning, 1(4).

Kozol, J. (1991). Savage inequalities. New York, NY: Crown Publishers.

Levin, B. (1993). Why so little educational reform in Canada? Studies in Educational Reform, 58, 41-48.

Levin, B. (1995a). Educational responses to poverty. Canadian Journal of Education, 20(2), 211-224.

Levin, B. (1995b). Poverty and education. Education Canada, 35(2), 28-35.

Levin, B. (2001a). Reforming education: From origins to outcomes. London, UK: Routledge Falmer.

Levin, B. (2001b). Governments and school improvement. International Electronic Journal for Leadership in Learning, 5(9).

Lieberman, A. (Ed.). (1990). Schools as collaborative cultures: Creating the future now. Philadelphia, PA: Falmer Press.

Lieberman, A. (1992). The changing contexts of teaching. Chicago, IL: University of Chicago Press.

Lieberman, A., \& Miller, L. (1990). Restructuring schools: What matters and what works. Phi Delta Kappan, 71(10), 759-764.

Lipsky, D. K., \& Gartner, A. (1989). Beyond separate education: Quality education for all. Baltimore, MD: Paul H. Brookes.

Lloyd, C, (2000). Excellence for all children-false promises! The failure of current policy for inclusive education and implications for schooling in the $21^{\text {st }}$ century. International Journal of Inclusive Education, 4(2), 133-151.

Lloyd, J. W., Singh, N. N., \& Repp, A. C. (1990). The regular education initiative: Alternative perspectives on concepts, issues, and models. Sycamore, IL: Sycamore Publishing Company.

Lovitt, T. C. (1993). Retrospect and prospect. In J. I. Goodlad \& T. C. Lovitt (Eds.), Integrating general and special education (pp. 253-274). New York, NY: Macmillan.

Lupart, J. L. (1998). Setting right the delusion of inclusion: Implications for Canadian schools. Canadian Journal of Education, 23(3), 251-264.

Lupart, J. L., Goddard, T., Hebert, Y., Jacobsen, M., \& Timmons, V. (2002). Students at risk in Canadian schools and communities. Report for the Child, Youth and Social Development Studies Division (CYSD) of the Applied Research Branch, Strategic Policy, Human Resources Development Canada.

Lusthaus, E., \& Lusthaus, C. (1992). From segregation to full inclusion: An evolution. Exceptionality Education Canada, $2(1 \& 2), 1-7$.

MacMillan, D. L., \& Hendrick, I. G. (1993). Evolution and legacies. In J. I. Goodlad \& T. C. Lovitt (Eds.), Integrating general and special education (pp. 23-48). New York, NY: Macmillan.

Mann, D. (1978). The user-driven system and a modest proposal. In D. Mann (Ed.), Making change happen? (pp. 285-307). New York, NY: Teachers College Press.

Maxcy, S. J. (2002). Ethical school leadership. Lanham, MD: Scarecrow Press.

McLaughlin, M. A. (1992). Employability skills profile: What are employers looking for? Ottawa, ON: The Conference Board of Canada.

McLaughlin, M. W. (1978). Implementation as mutual adaptation: Change in classroom organization. In D. Mann (Ed.), Making change happen? (pp. 19-31). New York, NY: Teachers College Press. 
McLaughlin, M. W., \& Marsh, D. D. (1979). Staff development and school change. In A. Lieberman \& L. Miller (Eds.), Staff development: New demands, new realities, new perspectives (pp. 69-94). New York, NY: Teachers College Press.

Meyen, E. L. (1995). Legislative and programmatic foundations of special education. In E. L. Meyen \& T. M. Skrtic (Eds.), Special education and student disability: An introduction (pp. 33-96). Denver, CO: Love Publishing Company.

Meyen, E. L., \& Skrtic, T. M. (Eds.). (1995). Special education and student disability: An introduction. Denver, CO: Love Publishing Company.

Moore, A., George, R., \& Halpin, D. (2002). The developing role of the head teacher in English schools: Management, leadership in pragmatism. Educational Management and Administration, 30(2), 175-188.

Murphy, J. (1991). Restructuring schools: Capturing and assessing the phenomena. New York, NY: Teachers College Press.

Nagy, P. (1995). Accountability in a broader context. Canadian Journal of Education, 20(1), 92-98.

National Association of Secondary School Principals. (1992). A leader's guide to school restructuring. Reston, VA: Author.

National Commission on Excellence in Education. (1983). A nation at risk: The imperative for educational reform. Washington, DC: Author.

National Education Goals Panel. (1991). The national education goals report: Executive summary. Washington, DC: Author.

Ng, H. M. (2001). 'Creation of income' by schools in China: A survey of selected schools in Guangzhou. Educational Management and Administration, 30(2), 379-395.

O'Neil, J. (1994). Can inclusion work? A conversation with Jim Kauffman and Mara Sapon-Shevin. Educational Leadership, 52(4), 7-11.

Parker, F., \& Parker, B. J. (1995). A historical perspective on school reform. The Educational Forum, 59, $278-287$.

Phillips, J. (2001). Education reform-Greek tragedy or Whitehall farce? Management in Education, 15(3), 1214.

Poetter, T. S., \& Knight-Abowitz, K. (2001). Possibilities and problems of school choice. Kappa Delta Pi Record, 37(2), 58-62.

Pogrow, S. (2002). Success for all is a failure. Phi Delta Kappan, 83(6), 463-468.

Porter, G. L., \& Richler, D. (Eds.). (1991). Changing Canadian schools: Perspectives on disability and inclusion. North York, ON: The Roeher Institute.

Powell, A. B., Farrar, E., \& Cohen, D. K. (1985). The shopping mall high school: Winners and losers in the educational marketplace. Boston, MA: Houghton Mifflin.

Presseisen, B. A. (1985). Unlearned lessons: Current and past reforms for school improvement. Philadelphia, PA: Falmer Press.

Pugach, M. C., \& Warger, C. L. (1993). Curriculum considerations. In J. I. Goodlad \& T. C. Lovitt (Eds.), Integrating general and special education (pp. 125-148). New York, NY: Merrill.

Reynolds, M. C. (1989). An historical perspective: The delivery of special education to mildly disabled and atrisk students. Remedial and Special Education, 10(6), 7-11.

Reynolds, M. C., Wang, M. C., \& Walberg, H. J. (1987). The necessary restructuring of special and regular education. Exceptional Children, 53, 391-398.

Robertson, J. M., \& Webber, C. F. (2000). Cross cultural leadership development. International Journal of Educational Leadership, 3(4), 315-330.

Rowan, B. (1990). Applying conceptions of teaching to organizational reform. In R. F. Elmore (Ed.), Restructuring schools: The next generation of educational reform (pp. 31-58). San Francisco, CA: JosseyBass.

Sarason, S. B. (1990). The predictable failure of school reform: Can we change course before it's too late? San Francisco, CA: Jossey-Bass.

Sashkin, M., \& Egermeier, J. (1992). School change models and processes: A review and synthesis of research and practice (Working Paper PIP 92-9). Washington, DC: Office of Educational Research and Improvement Programs for the Improvement of Practice. 
Schlechty, P. C. (1990a). Schools for the twenty-first century: The conditions for invention. In A. Lieberman (Ed.), Schools as collaborative cultures: Creating the future now (pp. 233- 255). Philadelphia, PA: Falmer Press.

Schlechty, P. C. (1990b). Schools for the twenty-first century: Leadership imperatives for educational reform. San Francisco, CA: Jossey-Bass.

Schonert-Reichl, K. (2000). Children and youth at risk: Some conceptual considerations. Paper commissioned by the Pan-Canadian Educational Research Agenda Symposium: Children and Youth at Risk. Ottawa, ON.

Schrag, J. A. (1993). Restructuring schools for better alignment of general and special education. In J. I. Goodlad \& T. C. Lovitt (Eds.), Integrating general and special education (pp. 203-227). New York, NY: Merrill.

Sergiovanni, T. J. (1992). Moral leadership: Getting to the heart of school improvement. San Francisco, CA: Jossey-Bass.

Sizer, T. R. (1984). Horace's compromise: The dilemma of the American high school. Boston, MA: Houghton Mifflin.

Sizer, T. R. (1992). A working design: The coalition of essential schools and re:learning. In National Association of Secondary School Principals (Ed.), A leader's guide to school restructuring: A special report of the NASSP Commission on Restructuring (pp. 23-29). Reston, VA: National Association of Secondary School Principals.

Skrtic, T. M. (1991). Behind special education: A critical analysis of professional culture and school organization. Denver, CO: Love Publishing.

Skrtic, T. M. (1995). The crisis in professional knowledge. In E. L. Meyen \& T. M. Skrtic (Eds.), Special education and student disability: An introduction (pp. 567-607). Denver, CO: Love Publishing Company.

Skrtic, T. M. (1996). School organization, inclusive education, and democracy. In J. Lupart, A. McKeough, \& C. Yewchuk (Eds.), Schools in transition: Rethinking regular and special education (pp. 81-118). Toronto, $\mathrm{ON}$ : Nelson Canada.

Smith, S. C., \& Scott, J. J. (1990). The collaborative school. Eugene, OR: ERIC/NASSP.

Smith, W. J. (1994). Equal educational opportunity for students with disabilities: Legislative action in Canada. Montreal, QC: Office of Research on Educational Policy, McGill University.

Smith, W. J., \& Foster, W. F. (2000). Equal educational opportunity for students with disabilities in Canada: A moral or legal right? In J. Andrews \& J. L. Lupart (Eds.), The inclusive classroom: Educating exceptional children (pp. 49-91). Toronto, ON: Nelson.

Stainback, S. B., \& Stainback, W. C. (1996). Merging regular and special education: Turning classrooms into inclusive communities. In J. Lupart, A. McKeough, \& C. Yewchuk (Eds.), Schools in transition: Rethinking regular and special education (pp. 43-59). Toronto, ON: Nelson Canada.

Stainback, W., \& Stainback, S. (1992). Controversial issues confronting special education: Divergent perspectives. Boston, MA: Allyn \& Bacon.

Stainback, W., Stainback, S., \& Bunch, G. (1989a). Introduction and historical background. In S. Stainback, W. Stainback, \& M. Forest (Eds.), Educating all students in the mainstream of regular education (pp. 3-14), Baltimore, MD: Paul H. Brookes.

Stainback, W., Stainback, S., \& Bunch, G. (1989b). A rationale for the merger of regular and special education. In S. Stainback, W. Stainback, \& M. Forest (Eds.), Educating all students in the mainstream of regular education (pp. 15-26), Baltimore, MD: Paul H. Brookes.

Stainback, W. Stainback, \& M. Forest (Eds.). (1989). Educating all students in the mainstream of regular education, Baltimore, MD: Paul H. Brookes.

Stiggins, R. J. (2002). Assessment crisis: The absence of assessment for learning. Phi Delta Kappan, 83(10), $758-765$.

Tanner, D. (2000). Manufacturing problems and selling solutions: How to succeed in the education business without really educating. Phi Delta Kappan, 82(3), 188-202.

Taylor, A. (2001). The politics of educational reform in Alberta. Toronto, ON: University of Toronto Press.

Tomlinson, H. (2001). Recent development in England and Wales: The national professional qualifications for headship (NPQH) and the leadership programme for serving head teachers. International Studies in Educational Administration, 29(2), 50-60. 
Tucker, C. M., Vogel, D. L., Keefer, N. L., Reid, A. D., Caraway, K., Reinke, W. M., \& Herman, K. C. (2002). Maladaptive behavior in African-American children: A self-regulation theory-based approach. The Educational Forum, 66(3), 220-227.

Turnbull, A. P., \& Turnbull, H. R. III. (1997). Families, professional, and exceptionality: A special partnership (3rd ed.). Saddle River, NJ: Merrill.

Vaughan, A. C. (2002). Standards, accountability, and the determination of school success. Educational Forum, 66(3), 206-213.

Villa, R. A., Thousand, J. S., Stainback, W., \& Stainback, S. (1992). Restructuring for caring and effective education. Baltimore, MA: Brookes.

Wang, M. C. (1990). Learning characteristics of students with special needs and the provision of effective schooling. In M. C. Wang, M. C. Reynolds, \& H. J. Walberg (Eds.), Special education research and practice (pp. 1-34). Oxford: Pergamon Press.

Wang, M. C. (1996). Serving students with special needs through inclusive education approaches. In J. Lupart, A. McKeough, \& C. Yewchuk (Eds.), Schools in transition: Rethinking regular and special education (pp. 143-163). Toronto, ON: Nelson Canada.

Wang, M. C., Haertel, G. D., \& Walberg, H. J. (1990). What influences learning? A content analysis of review literature. The Journal of Educational Research, 84(1), 30-43.

Wang, M. C., \& Reynolds, M. C. (1985). Avoiding the "Catch 22" in special education reform. Exceptional Children, 51, 497-502.

Wang, M. C., Reynolds, M. C., \& Walberg, H. J. (1994). Serving students at the margins. Educational Leadership, 52(4), 12-17.

Weatherley, R., \& Lipsky, M. (1978). Street-level bureaucrats and institutional innovation: Implementing special education reform. In D. Mann (Ed.), Making change happen? (pp. 49-77). New York, NY: Teachers College Press.

Webber, C. F. (1994). School culture. In R. R. O’Reilly \& S. Sikora (Eds.), Becoming a Canadian teacher (pp. 152-167). Calgary, AB: University of Calgary.

Webber, C. F. (1995). The early effects of mandated change in Alberta. The Canadian Administrator, 34, 111.

Whitty, G., Power, S., \& Halpin, D. (1998). Devolution and choice in education: The school, the state, and the market. Melbourne, Australia: Australian Council for Educational Research.

Will, M. (1986). Educating children with learning problems: A shared responsibility. Exceptional Children, $52,411-415$.

Winzer, M. A. (1996). Children with exceptionalities in Canadian classrooms (4th ed.). Scarborough, ON: Allyn \& Bacon Canada.

Wolfensberger, W. (1984). Social role valorization: A proposed new term for the principle of normalization. Mental Retardation, 21(6), 234-239.

Wolfensberger, W., Nirge, B., Olshansky, S., Perske, R., \& Roos, P. (1972). The principle of normalization in human services. Toronto, ON: National Institute on Mental Retardation.

Wong, B. Y. L. (1996). The TEAM model: A potential model for merging special education with regular (general) education. In J. Lupart, A. McKeough, \& C. Yewchuk (Eds.), Schools in transition: Rethinking regular and special education (pp. 194-270). Toronto, ON: Nelson Canada.

Yewchuk, C. (1996). Gifted education and school reform. In J. Lupart, A. McKeough, \& C. Yewchuk (Eds.), Schools in transition: Rethinking regular and special education (pp. 164-193). Toronto, ON: Nelson Canada.

\section{Authors' Note}

Correspondence concerning this article should be addressed to Judy Lupart, Department of Educational Psychology, University of Alberta, Edmonton, AB, T6G 2G5.

Email: judy.lupart@ualberta.ca 